\title{
PROSES PEMBENTUKAN BIOPATINA PADA BATUAN
}

\author{
Danni Gathot Harbowo \\ Program Studi Jurusan Biologi \\ Sekolah Ilmu dan Teknologi Hayati, Institut Teknologi Bandung
}

\section{Pengertian Biopatina}

Biopatina merupakan keadaan batuan yang telah mengalami perubahan warna akibat aktifitas mikroorganisme dalam jangka waktu yang relatif lama (Krumbein, 1997). Perubahan warna batuan ini disebabkan oleh beberapa hal, diantaranya adalah karena adanya reaksi reduksi-oksidasi (redoks) pada batuan yang mampu mengubah struktur kristal pada mineral batuan (Puente, 2005) dan terdapatnya pigmen mikroorganisme yang tersisa pada permukaan batuan (Krumbein, 1997). Pigmen yang dihasilkan oleh mikroorganisme memiliki warna yang spesifik dan beragam bergantung pada jenis mikroorganisme dan media tumbuhnya (Black, 2005).

Dalam beberapa jajak pendapat (Krumbein, 1997), penampakan biopatina pada suatu objek menunjukan nilai klasik yang lebih tinggi. Kemunculan warna tua akan terasa pada objek yang telah mengalami patina. Hal ini disebabkan proses patina terjadi dalam waktu yang sangat lama, mencapai waktu 3000 tahun proses. Terminologi patina pertama kali didefinisikan oleh Filippo Baldinucci pada tahun 1681 yang didokumentasikan pada Dictionary of Art. Dalam kamus ini patina didefinisikan sebagai penurunan kecerahan pada lukisan dinding seiring dengan lamanya waktu. Pada abad
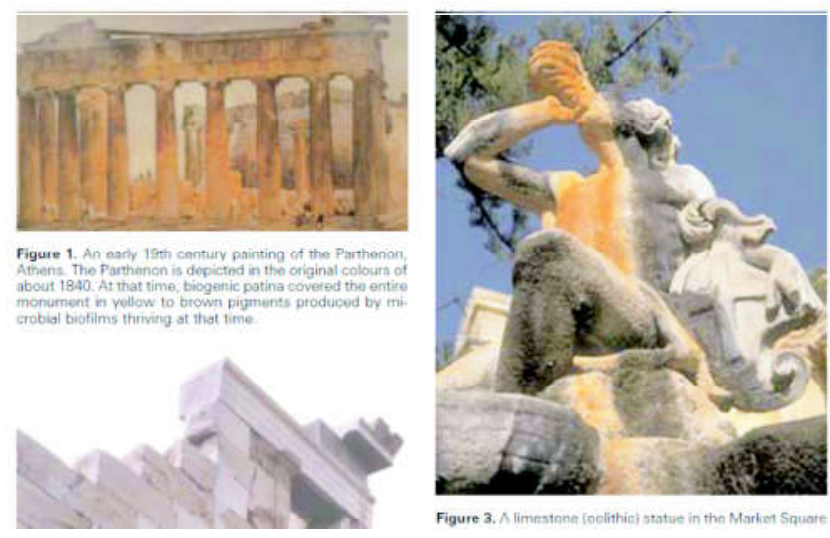

Gambar 1.1.

Patung Statue Piazza Armerina di Sicity (kiri) dan bangunan Parthenon di Athena (kanan) yang mengalami perubahan warna akibat reaksi redoks pada biosistensis dan sisa pigmen yang dihasilkan oleh bakteri dan jamur dibeberapa bagian batuan. penyusun. (Sumber: Krumbein, 1997)

18, terminologi patina digunakan untuk istilah pada perubahan warna pada perak dan perunggu yang

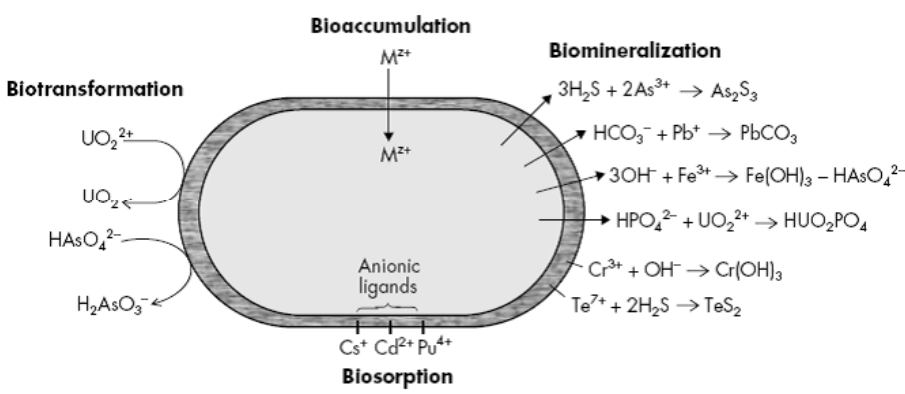

Gambar 2.1

Beberapa mekanisme intraseluler sel yang mampu menyebabkan perubahan bilangan oksidasi pada unsur logam (Sumber: Chaerun, 2010)

disebabkan oleh oksidasi logam. Pada tahun 1985, istilah patina diartikan sebagai seluruh perubahan pada semua tipe material yang digunakan sebagai objek seni, seperti pahatan batuan atau kayu, lukisan, dan barang seni lainnya.

Terdapat beberapa mekanisme selluler yang mampu menyebabkan perubahan bilangan oksidasi pada logam, yaitu mekanisme bioaccumulation, biotransformation, bioabsorption, dan biomineralization. Keempat mekanisme ini mampu menyebabkan perubahan bentuk kristal dan bilangan oksidasi unsur dalam suatu mineral (Chaerun, 2010). Bioaccumulation adalah mekanisme intraseluler suatu organisme dalam mengakumulasikan suatu unsur untuk disimpan di dalam tubuhnya. Sebelum diakumulaisikan di dalam sel, unsur tersebut akan diubah bilangan oksidasinya dengan mekanisme biosintetik tertentu sehingga unsur tersebut dapat melewati channel protein yang ada pada membran sel. Unsur yang akan diakumulasikan tersebut akan disimpan dalam sitoplasma sel dan berperan dalam biosintetik. Biotransformation adalah suatu proses perubahan senyawa (mineral) yang disebabkan oleh aktifitas sel yang kemudian akan kembali disekresikan. Sel akan menghasilkan senyawa sekret yang mampu mengubah bilangan oksidasi pada suatu mineral. Proses transformasi ini dilakukan oleh sel untuk mendapatkan energi dari perubahan bilangan oksidasi suatu mineral. Sedangkan pada bioabsorption, sel akan menghasilkan ligand organik yang berada di membran sel, ligand tersebut akan mengikat logam yang ada di sekitar sel dengan perubahan bilangan oksidasi. Biomineralization merupakan proses pembentukan mineral oleh organisme, unsur tertentu akan direaksikan dengan unsur lainnya 
sehingga membentuk suatu mineral.

Pada umumnya reaksi redoks pada mineral yang disebabkan oleh mikroorganisme dipicu oleh adanya senyawa asam organik (Carey, 2003) yang mampu mengubah bilamgan oksidasi pada suatu unsur yang ada di sekitar permukaan. Dalam formasi mineral yang mengandung logam, jenis logam dan struktur kristal memegang peran dalam memberikan penampakan warna pada batuan. Perubahan bilangan oksidasi pada logam akan memberikan warna penampakan yang berbeda. Selain itu perubahan bilangan oksidasi pada logam juga mampu menyebabkan perubahan struktur kristal (geometri) pada batuan (Bank, 2004). Perubahan struktur kristal tersebut akan menyebabkan penampakan warna
2005).

Reaksi redoks digunakan oleh sel untuk mereduksi agen (senyawa) oksidator sehingga menghasilkan energi untuk proses metabolismenya. Namun reaksi redoks tersebut membutuhkan agen reduktor agar terjadi keseimbangan pada reaksi redoks tersebut (Carey,. 2003). Logam sering kali digunakan oleh mikrooganisme sebagai kofaktor enzim, ion pada senyawa kompleks, akseptor elektron, dan sumber energi pada proses metabolisme intraseluler (Alberts, 2008). Untuk memenuhi kebutuhan unsur logam tersebut, mikroorganisme akan menghasilkan asam yang mampu mengubah bilangan oksidasi logam yang ada di sekitarnya sehingga mudah untuk diserap oleh sel melalui channel
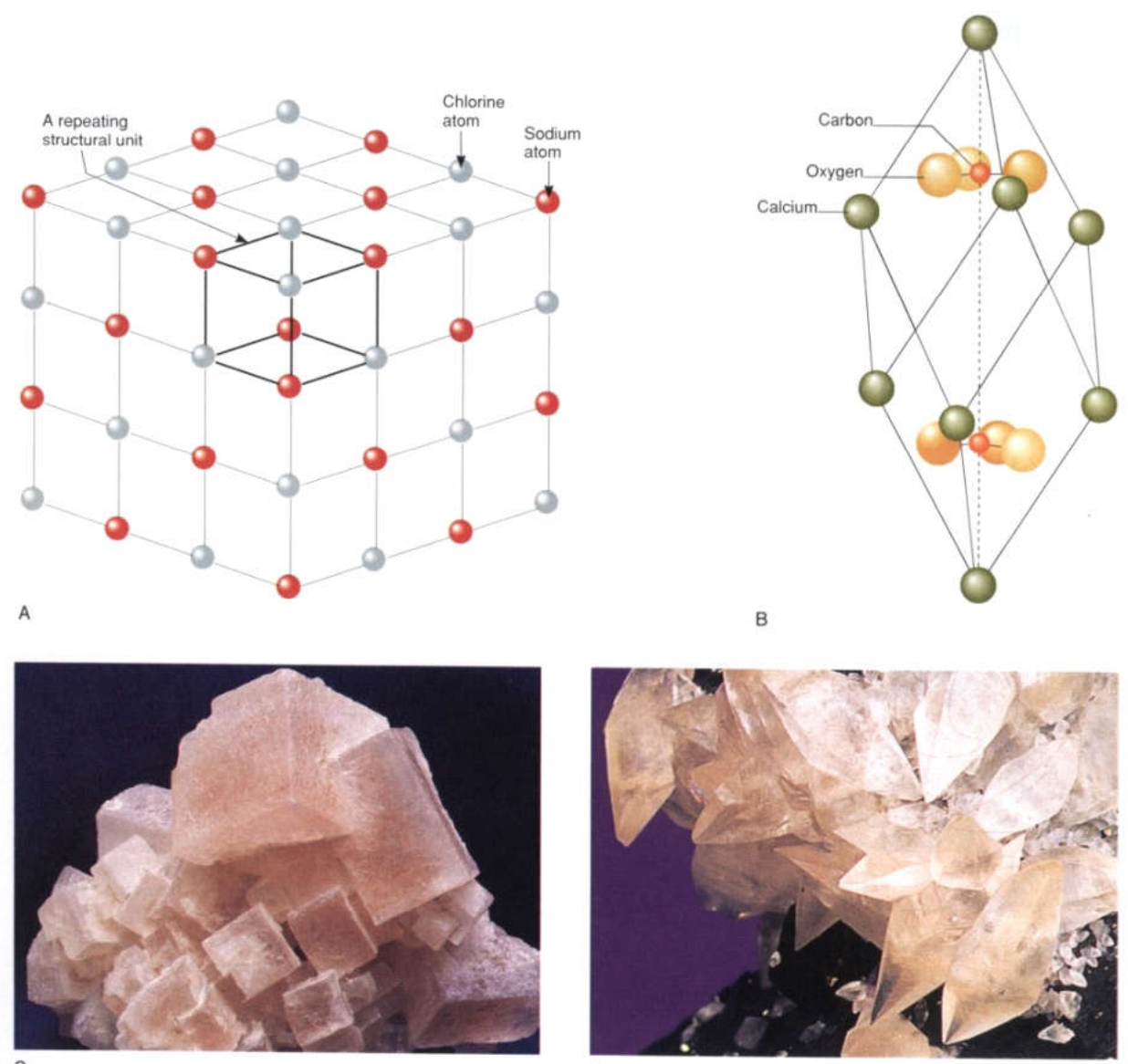

Gambar 2.2

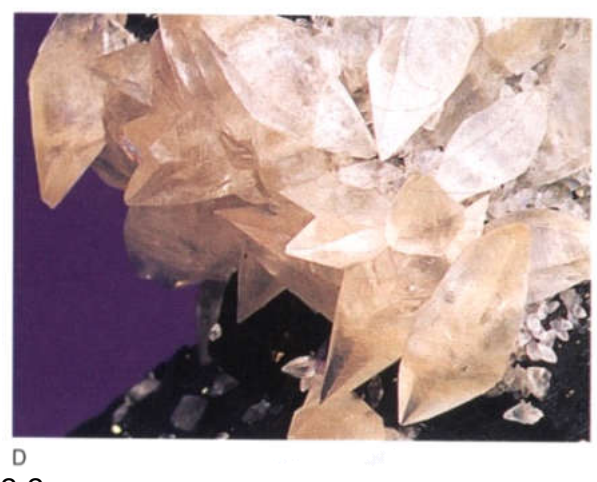

2

Penyusun unsur dan struktur mineral yang berbeda akan menghasilkan penampakan warna mineral yang berbeda. Ket: (A) merupakan ilustrasi geometri dasar kristal halite,( B) ilustrasi geometri dasar kristal kalsit. (C) penampakan makroskopik halite, (D) penampakan makroskopik (Sumber: Chaerun, 2010)

protein. Selain itu juga dalam proses metabolismenya sel membutuhkan akseptor elektron berupa senyawa logam pada proses transfer elektron ketika terjadi metabolisme anaerob.

Pada um un y a akseptor yang digunakan pada mekanisme tersebut adalah gas oksigen $\left(\mathrm{O}_{2}\right)$ (Alberts, 2008). Gas oksigen akan yang akan direduksi menjadi oksigen biloks $-2\left(\mathrm{O}^{-2}\right)$ yang kemudian mampu menangkap elektron untuk pembentukan adenosine triphospat atau ATP (Black, 2005), mekanisme ini disebut dengan metabolisme aerob. Namun jika ketersedian oksigen tidak ada $\mathrm{p}$ a d a $1 \mathrm{ing} \mathrm{k} \mathrm{ng}$ a n, mikroorganisme tersebut akan menggunakan akseptor elektron lainnya seperti sulfur atau logam. Mekanisme ini disebut dengan metabolisme anaerob. Pada umumnya proses anaeroba menghasilkan senyawa residu berupa asam. Jenis asam yang dihasilkan seperti asam laktat dan asam oksalat, senyawa asam ini merupakan senyawa asam lemah namun dalam keadaan tertentu

yang dipantulkan oleh batuan menjadi berbeda dari keadaan normal. Penampakan warna yang berbeda pada suatu kristal mineral batuan disebabkan karena adanya perbedaan formasi atom pada mineral tersebut (Puente, mampu memicu reaksi redoks.

Dalam suatu pertumbuhan mikroorganisme di sebuah media tumbuh (termasuk batuan), seringkali membentuk suatu lapisan (layer) koloni dalam luas area 


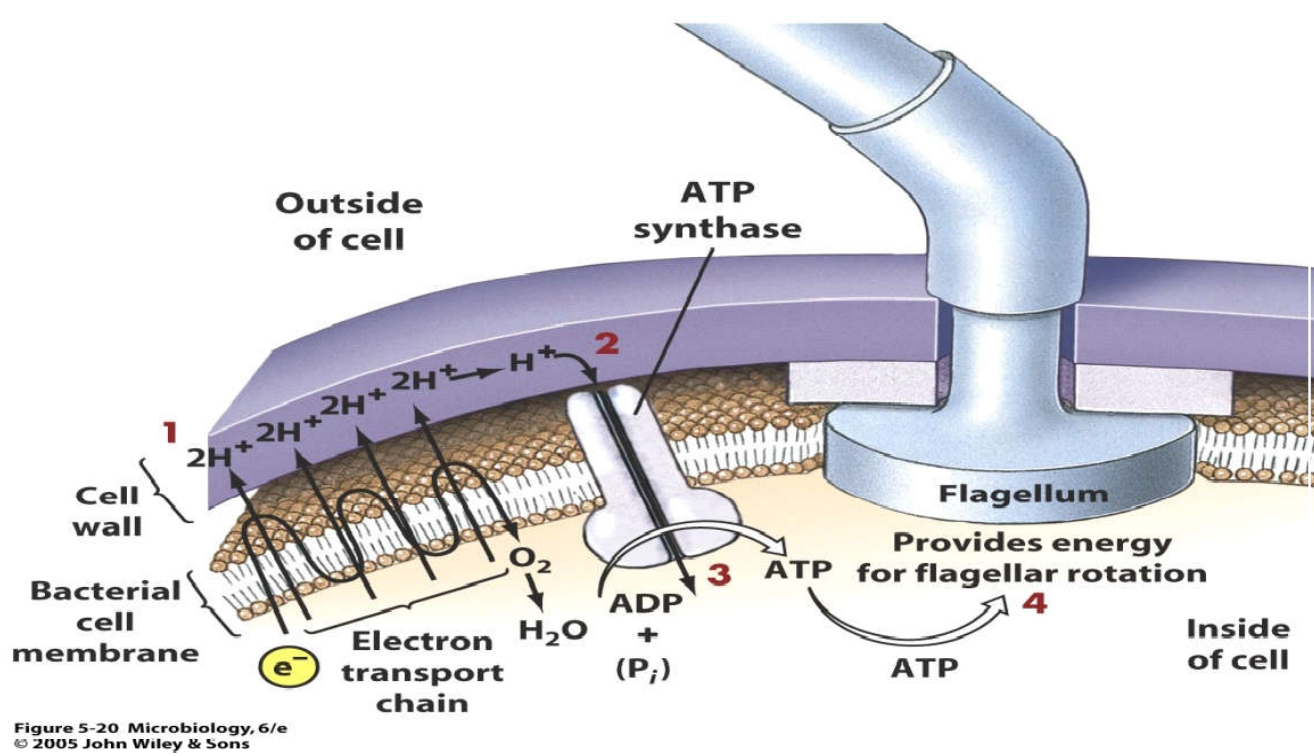

Gambar 2.3

Proses mekanisme transfer elektron secara aerob pada bakteri untuk menghasilkan energi kimia berupa senyawa ATP (Sumber: Black, 2005) tersebut dapat digolongkan sebagai mikrooganisme photothropic. Namun beberapa jenis mikroorganisme photophobic (Black, 2005), juga menggunakan senyawa komplek-ligand (seperti pigmen) yang memiliki penampakan warna tertentu sebagai konvertor energi kimia dalam wujud anorganik menjadi energi kimia organik (Madigan,. 2009). Umumnya pigmen yang dihasilkan oleh mikroorganisme tersebut merupakan senyawa organik yang membentuk formasi kompleks (ligand) yang mampu berikatan dengan logam seperti pigmen klorofil. Pembentukan tertentu. Pembentukan biofilm ini dapat terjadi akibat pertumbuhan mikroorganisme secara vertikal yang kemudian akan membentuk lapisan - lapisan (strata) koloni. Pembentukan biofilm pada pada permukaan batuan akan menyebabkan mikroorganisme di beberapa bagian batu mengalami kekurangan oksigen. Mikroorganisme yang berada paling bawah akan memiliki keadaan lebih anaerob dibandingkan mikroorganisme yang berada paling atas (Madigan,. 2009). Reaksi anaerob ini akan semakin meningkat seiring semakin rendahnya kadar oksigen pada lingkungan mikroorganisme tersebut. Ketika pembentukan biofilm ini terjadi pada batuan maka perubahan bilangan oksidasi material batuan akan dapat terjadi, Dampaknya permukaan batuan akan mengalami perubahan, baik perubahan warna ataupun perubahan struktur. Mekanisme seperti inilah yang terjadi pada batuan dalam beberapa kasus yang mengalami biopatina (Krumbein, 1997).

Selain itu, pembentukan pigmen oleh suatu organisme (khususnya mikroorganisme) pada suatu batuan juga akan menyebabkan perubahan penampakan batuan (Krumbein, 1997). Selain perubahan struktur permukaan batuan, aktifitas biologis tersebut (pembentukan pigmen) akan menyebabkan perubahan warna pada batuan. Pigmen yang dihasilkan tersebut digunakan oleh mikroorganisme untuk proses biosintetik dalam perolehan energi (Carey,. 2003). Beberapa jenis pigmen yang dihasilkan akan berperan dalam mengkonversi energi foton dari cahaya matahari menjadi energi kimia melalui proses fotosistensis, mikroorganisme penampakan tertentu jika berikatan dengan logam

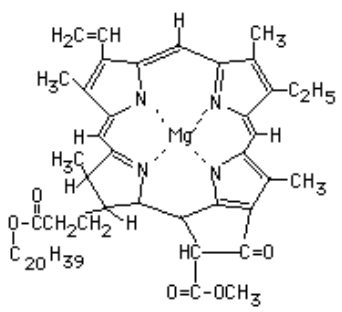

Chlorophyll a

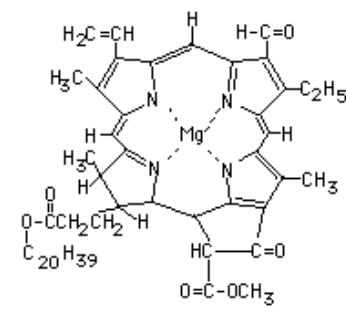

Chlorophyll b<smiles>CC1=C(/C=C/C=C/C=C/C=C/C=C/C=C/C=C/C=C(C)/C=C/C2=C(C)CCCC2(C)C)C(C)(C)CCC1</smiles><smiles>CC1=C(/C=C/C(C)=C/C=C/C=C/C=C/C=C/C(C)=C/C=C/C2=C(C)CCC(O)CC2(C)C)C(C)(C)CCC1</smiles>

\section{Gambar 2.4}

Beberapa pigmen yang dihasilkan mikroorganisme yang memiliki penampakan warna tertentu yang berperan dalam proses fotosintentis. (sumber: Madigan,. 2009)

tertentu (Carey,. 2003).

Jenis pigmen yang dapat ditemukan dalam aktifitas pembentukan biopatina diantaranya adalah pigmen krolofil, karotenoid, melanin, dan mycosporin senyawa kompleks tersebut akan menghasilkan warna 
(Krumbein, 1997). Warna yang ditimbulkan dari proses biopatina bergantung pada jenis mikroorganisme, jenis pigmen yang dihasilkan, dan komposisi media tumbuhnya. Mikroorganisme yang berperan dalam proses biopatina diantaranya adalah mikroorganisme golongan bakteri, jamur, alga dan lichen. Keempat golongan mikroorganisme ini memiliki jalur metabolisme tertentu yang mampu menghasilkan pigmen untuk proses biosintetiknya (Madigan,. 2009).

\section{Pengaruh Biopatina terhadap Batuan Cagar Budaya}

Berdasarkan proses terbentuknya, biopatina dapat menyebabkan perubahan warna, komposisi dan struktur pada permukaan batuan. Namun proses ini memerlukan waktu 50 - 100 tahun agar terlihat jelas perubahan yang terjadi. Dalam beberapa benda cagar budaya, biopatina umum terjadi secara alami (Krumbein, 1997). Pertumbuhan biopatina ini dipengaruhi oleh keadaan mikroklimat di sekitar benda cagar alam tersebut. Dalam beberapa jajak pendapat, keterdapatan biopatina pada suatu benda cagar alam (khusunya pada batuan) dapat menunjukan nilai klasik yang lebih tinggi. Keberadaan biopatina pada suatu batuan menunjukan bahwa benda tersebut tidak mengalami gangguan (pengikisan) permukaan dalam waktu yang lama (mencapai ratusan tahun) (Krumbein, dalam Golan, 2011). Hal ini disebabkan pertumbuhan mikroorganisme pada suatu batuan membutuhkan waktu yang sangat lama seiring dengan umur benda tersebut dan menunjukan bahwa pada permukaan batuan tersebut tidak mengalami pengikisan permukaan.

Perubahan warna pada permukaan batuan dapat terjadi akibat sisa pigmen mikroorganisme yang ada pada permukaan batuan. Warna yang terbentuk tersebut bergantung pada jenis dan jalur metabolisme mikroorganisme yang tumbuh pada batuan tersebut. Setiap pigmen akan memiliki penampakan warna tertentu, pigmen klorofil akan memberikan penampakan warna hijau. Pigmen karotenoid akan memberikan penampakan warna jingga atau kuning sedangkan pigmen melanin akan memberikan penampakan hitam. Ketika mikrorganisme tersebut mati di permukaan batuan maka pigmen warna tersebut akan tetap ada pada batuan tersebut hingga akhirnya membentuk lapisan kerak pada batuan.

Aktifitas mikroorganisme pada batuan memungkinkan terjadi perubahan komposisi pada permukaan batuan. Metabolit sekunder (zat sekret) dan sisa metabolisme yang dihasilkan oleh mikrooganisme mampu menyebabkan reaksi pada komposisi yang ada di permukaan batuan (misalnya batuan andesit). Komposisi yang ada pada batuan andesit memiliki kandungan mineral yang berguna untuk proses biosintetik sel, seperti kalsium, natrium, phospat, besi, dan magnesium. (Chaerun, 2010).

Namun unsur tersebut memiliki formasi oksida di alam. Agar sel dapat mengekstrak unsur tersebut sel akan menghasilkan senyawa biosintetik yang mampu mengionisasi senyawa (pada umumnya melalui reaksi redoks) tersebut sehingga dapat diserap sel melalui channel protein. Perubahan komposisi tersebut dapat menyebabkan penggaraman pada batuan sehingga akan terjadi perubahan warna. Garam tersebut dapat larut dan terkikis bersama air, bergantung pada koofisien kelarutannya garam yang dihasilkan. Namun dalam keadaan tertentu (misalnya panas-kering), garam tersebut dapat membantu dalam penutupan pori batuan sehingga mampu menghalangi air dan udara masuk ke dalam. Masuknya air dan udara pada pori batuan dapat menyebabkan pelapukan secara kimiawi, fisika, dan

andesit berwarna abu-abu kehitaman, sedangkan warna
dalam keadaan lapuk berwarna abu-abu kecoklatan,
berbutir halus sampai kasar, andesit mempunyai
kuat tekan berkisar antara 600-2400 kg/ $\mathrm{cm}^{2}$
dan berat jenis antara 2,3-2,7 bertekstur porfiritik,
keras dan kompak.

Tabel 1. Komposisi kimia Andesit

\begin{tabular}{|l|l|}
\hline Senyawa & Komposisi (\%) \\
\hline $\mathrm{SiO}_{2}$ & 47,55 \\
\hline $\mathrm{Al}_{2} \mathrm{O}_{3}$ & 18,37 \\
\hline $\mathrm{Fe}_{2} \mathrm{O}_{3}$ & 8,19 \\
\hline $\mathrm{CaO}$ & 7,11 \\
\hline $\mathrm{MgO}$ & 2,25 \\
\hline $\mathrm{Na}_{2} \mathrm{O}$ & 1,70 \\
\hline $\mathrm{K}_{2} \mathrm{O}$ & 2,16 \\
\hline $\mathrm{TiO}_{2}$ & 0,59 \\
\hline $\mathrm{MnO}$ & 0,22 \\
\hline $\mathrm{P}_{2} \mathrm{O}_{5}$ & 0,30 \\
\hline $\mathrm{H}_{2} \mathrm{O}$ & 0,52 \\
\hline
\end{tabular}

Tabel 3.1

Persentase komposisi senyawa andesit dalam satuan gram

(Sumber: Chaerun, 2010)

biologi. Keberadaan air dan udara pada pori batuan akan memberikan suasana aerob sehingga mikroorganisme dapat tumbuh lebih cepat pada bagian dalam batuan.

Perubahan komposisi dan bilangan oksidasi pada unsur batuan dapat menyebabkan perubahan struktur geometri pada kristal mineral batuan. Perubahan stuktur 
ini mampu menyebabkan perubahan morfologi makroskopik pada permukaan batuan bergantung pada stuktur geometrinya. Pada umumnya akan terjadi pembentukan postule pada batuan yang kemudian akan membentuk cekungan, proses ini lebih dikenal dengan biopitting, yaitu pembentukan cekungan yang disebabkan oleh aktifitas mikroorganisme. Selain itu, aktifitas mikroorganisme pada batuan mampu menyebabkan pembentukan kerak. Pembentukan kerak tersebut dalam jangka waktu yang lama dapat merubah penampakan stuktur batuan yang berbeda.

Untuk menganalisis biopatina pada batuan dapat digunakan beberapa metode seperti isolasi agen biopatina batuan dengan menggunakan metode analisis mikroskopik konvensional (Madigan,. 2009), menggunakan metode pengukuran dengan spektofotometri, untuk mengukur kandungan pigmen yang dihasilkan oleh mikroorganisme (Carey, 2003). Sedangkan untuk menganalisis efek dari biopatina terhadap batuan dapat dianalisis dengan metode determinasi dengan Scanning Electron Microscope (SEM) (Puente, 2005). Dengan rangkaian analisis tersebut diharapkan perawatan benda purbakala untuk menghindari aktifitas mikroorganisme tersebut dapat ditangani dengan tepat. Pengunaan metode yang tepat dalam penanganan biopatina tersebut akan menghindari kerusakan pada objek konservasi dan resistensi pada mikroorganisme.

\section{Kesimpulan}

Biopatina merupakan suatu proses pada batuan yang dapat menyebabkan perubahan warna, komposisi, dan struktur pada permukaan batuan akibat adanya aktifitas mikroorganisme dalam jangka waktu yang relatif lama. Keberadaan biopatina pada suatu objek menunjukan nilai klasik yang lebih tinggi karena menunjukan bahwa benda tersebut memiliki umur yang sangat tua dan memiliki intensitas gangguan permukaan yang relatif kecil. Berdasarkan aktifitas mikroorganisme, terdapat beberapa mekanisme seluler yang mampu menyebabkan biopatina pada logam batuan, yaitu mekanisme bioaccumulation, biotransformation, bioabsorption, dan biomineralisasi. Logam pada batuan ini digunakan oleh mikrooganisme pada berbagai proses metabolisme intraseluler.

Pembentukan biofilm pada permukaan batuan berperan dalam proses pembentukan biopatina. Biofilm tersebut akan menyebabkan mikroorganisme di beberapa bagian batu mengalami kekurangan oksigen sehingga terjadi reaksi anaerob yang mampu mengubah bilangan oksidasi unsur dan penggaraman. Selain itu, biopatina dapat terjadi akibat pembentukan pigmen oleh organisme (khususnya mikroorganisme) di permukaan batuan yang dapat menyebabkan perubahan penampakan batuan. Dengan adanya aktifitas mikroorganisme tersebut akan dimungkinkan pula terjadi perubahan komposisi pada permukaan batuan.

Berdasarkan pengaruhnya terhadap batuan, pembentukan biopatina dapat menimbulkan garam yang dapat menutupi pori batuan sehingga air dan udara tidak dapat masuk ke dalam pori. Dengan demikian batuan terhalangi dari proses pelapukan dalam keadaan tertentu. Proses biopatina juga dapat memicu terjadinya proses biopitting yang mampu membentuk cekungan dan penumpukan kerak pada batuan sehingga merubah penampakan stuktur batuan. Perubahan seperti ini dapat dianalisis dengan menggunakan beberapa metode terintegrasi.

\section{Daftar Pustaka}

Alberts, Bruce; et all. 2008. "Molecular Biology of The Cell 5 "b Edition". Garland Science: New York

Bank, Eric D; dkk. 2004. Bacterial Calcium Carbonate Precipitation in Cave Environments: A Function of Calcium Homeostasis. Geomikrobiology Journal Volume 22, Nomer 6, Agustus 2005.

Black, Jacquelyn G. 2005. Microbiology: Principles and Explorations Sixth Edition. John Wiley and Sons, Inc: San Franssisco

Carey, Francis.A. 2003. Organic Chemistry, $5^{\text {th }}$ Ed. New York :Mc Graw Hill

Chaerun ,Siti K. 2010. Prinsip dan Mekanisme Biomineralisasi. Presentasi Kuliah Biomineralogi. Sekolah Ilmu dan Teknologi Hayati, Institut Teknologi Bandung

Golan, Oded. 2011. The Authenticity of the James Ossuary and the Jehoash Tablet Inscriptions - Summary of Expert Trial Witnesses. Rangkuman Testimoni, Israel Antiquities Authority: Tel Aviv

Krumbein, Wolfgang E. 1997. Patina and Cultural Heritage - a Geomicrobiologist's Perspective. Biotechnologies in Cultural Heritage Protection and Conservation: Biodeterioration and its control

Madigan, Michael T; Martinko, John M; Dunlap, Paul V; dan Clark, David P. 2009. Brock: Biology of Microorganism 12th editon. Pearson Benyamin Cummings: San Francissco

Puente, M. Esther, dkk. 2005. Image Analysis for Quantification of Bacterial Rock. Weathering. Journal of Microbiological Methods 64 (2006) 275-286 